\title{
UTAK AZ ÉRTELMÜKBEN AKADÁLYOZOTT FELNŐTT SZEMÉLYEK MEGISMERÉSÉHEZ - ÖNKÉNTES KÁVÉHÁZI FELSZOLGÁLÁS, MINT EGY LEHETSÉGES ALTERNATÍVA
}

Szerzők:

Misák Darinka Vadvirág Esély Klub

Fogyatékosok Nappali Intézménye

Szerző e-mail címe:

misakdarinka197586@gmail.com

\section{Lektorok:}

\author{
Varga Imre \\ Szegedi Tudományegyetem \\ Hatos Gyula \\ Mező Katalin \\ Debreceni Egyetem \\ Nemes Magdolna \\ Debreceni Egyetem
}

Misák D. (2016): Utak az értelmükben akadályozott felnőtt személyek megismeréséhez Önkéntes kávéházi felszolgálás, mint egy lehetséges alternatíva. Különleges Bánásmód, II. évf., 2016/1. szám, 89-96. DOI 10.18458/KB.2016.1.89

\begin{abstract}
Absztrakt
E mühelymunka a pedagógiai kísérésre, azon belül, a felnött értelmükben akadályozott személyek munkába állitására fókuszál. A megfigyelés módszerére alapozva bemutatja azt a mentori felkészítö folyamatot, mely az olvasó elé tárja, hogy milyen támogatás szükséges ahhoz, hogy a fogyatékos személyek is képessé váljanak eredményes munkatevékenység elvégzésére. Fö célkitüzése, hogy a korlátozott képességü személyeket önkéntes munkán keresztül bemutassa, elfogadtassa a társadalom ép tagjaival. Nemcsak a pozitív hozadékokra fókuszál, hanem azokra a negatívumokra is, amelyeken dolgozniuk kell azon szakembereknek, akiknek hivatástudatukká vált a pedagógiai kísérés.
\end{abstract}

Kulcsszavak: pedagógiai kísérés, mentor, kávéházi felszolgálás, elméleti érzékenyítés

Diszciplina: gyógypedagógia

\footnotetext{
Abstract

WAYS FOR UNDERSTANDING mentally HANDICAPPED ADULTS - VOLUNTARY COFFEE SHOP SERVING AS A POSSIBLE ALTERNATIVE

This paper focuses on pedagogical attendance especially bringing adults with mental disability into action. Based on the method of observation, it presents the mentoring preparation procedure that reveals to the reader what sort of support is needed to make individuals with disabilities capable of doing successful labour activity. The main goal of the programme is to introduce individuals with limited abilities to the sound members of society
} 
through voluntary work and make them accepted. It draws attention not only to the positive increments but also to the very negatives that must be worked at by specialists whom have true calling to the profession of pedagogical attendance.

Keywords: pedagogical attendance, mentor, coffee shop service, theoretical sensitizing

Discipline: special education

Felemelni a gyengébbet egy adott feladathoz, támogatni, kísérni a fejlödésben, örülni a sikerének, ... az, egy csodálatos dolog.

Misák Darinka

Jelen tanulmány megírásában az a több, mint 17 éves gyakorlati és elméleti háttér segítette a Szerzőt, melyet felnőtt, értelmükben akadályozott személyek között tölthetett. Ez idő alatt nagyon sokat tanult tőlük, s a tanulás folyamán észrevétlenül vált közösségük tagjává, részévé. Nemcsak a szeretet nyílt és önzetlen áramlását lehetet azonban az értelmükben akadályozottak körében érezni a velük töltött időben, hanem fájdalmuk megnyilvánulásait is. „Ami téged megüt, megsebez, az engem is megüt, rajtam is sebet vág.” (Vanier, 1982, 88. o.)

A gyógypedagógusi munka során a pedagógiai kísérés egyik fontos elve, hogy gondozottjainkat olyan feladathelyzetekbe hozzuk, amelyek által nemcsak sikerélményt, önbizalmat kapnak, hanem a társadalmi környezet felé egy megismerési lehetőséget kínáljak, alkalmat a személyes kontaktusokra, az értelmileg akadályozott személyek emberközi megtapasztalására. „A felnőttnek már múltja van, s az értelmi fogyatékos felnőtt múltja gyakran szenvedések és elutasítások története. Mivel önképe sérült, túlságosan is hajlamos mindenért önmagát okolni. Az ilyen embert erősíteni, biztatni és támogatni kell.” - írja Vanier (2008, 27. o.).

Az értelmükben akadályozott felnőttek egyfajta (jó értelemben vett) munkaterápiája lehet az önkéntes kávéházi felszolgálásba történő bekapcsolódás, mely növelheti önértékelésüket, önbecsülésüket, s kedvező hatással lehet személyközi viszonyaikra. Az alábbiakban azt a folyamatot tekintjük át, amely felnőtt értelmükben akadályozott személyek önkéntes kávéházi felszolgálását taglalja. A kezdeti lépésektől egészen a konkrét munkavégzésig vesszük sorra a felmerülő teendöket, rávilágítva azokra a pozitív és negatív dolgokra, amelyekből a későbbiekben építkezni lehet elsősorban olyan személyeknek, akik a pedagógiai kísérést választották hivatásuknak.

Az önkéntes kávéházi felszolgálás szervezése és megvalósítása folyamán végzett mentori munka során a megfigyelés módszerével (Vasek, 2006) gyüjtöttünk adatokat, rögzítettük és jegyeztük le az észrevételeket, tapasztalatokat. E tapasztalatok szintézisét foglaljuk össze röviden az alábbiakban.

\section{Elözmények}

Hírfolyamban találkozhattunk azzal a cikkel, amely Ability Café címen bemutatott egy kéthetes kávéházi felszolgálást felnőtt értelmileg akadályozott személyek (a pécsi Fogd a Kezem Alapítvány ellátottjainak) bevonásával. Az orosházi Vadvirág Esély Klub Fogya- 
tékosok Nappali Intézmény akkori vezetője felvette a kapcsolatot a pécsi szervezettel, s jelezte, hogy ellátottjaival részt kíván venni ebben a projektben. 2015 év elején találkozó történt a két szervezet tagjai között, ahol a pécsi ellátottak elmesélték felszolgálói tapasztalataikat, élményeiket. Ezek után került elhatározásra, hogy amennyiben sikerül megteremteni a lehetőségeket úgy az orosházi Vadvirág Esély Klub is csatlakozni kíván a pécsi kezdeményezéshez. Így történt, hogy az országban az orosházi Vadvirág Esély Klub Fogyatékosok Nappali Intézménye a második olyan Intézmény a Pécsi Fogd a Kezem Alapitvány után, akik vállalták, hogy értelmükben akadályozott felnött személyeket úgymond „felkészítenek” egy kéthetes - önkéntességen alapuló - kávéházi felszolgálásra.

\section{Kiválasztás}

Önkéntes felszolgálók kiválasztása. Az orosházi Vadvirág Esély Klub 13 gondozottja jelezte, hogy szeretne részt venni az önkéntes kávéházi felszolgálást célzó projektben. Arra a kérdésre, hogy miért szeretnének részt venni, mindössze 8 jelentkező tudott válaszolni. Jellegzetes válaszok voltak: „Hogy büszkék legyenek rám a szüleim...”, „Hogy megmutathassam én is olyan vagyok, mint bárki más...”, „Hogy fejlödjek...”. Megtapasztalható volt az, amit Hatos (2008, 300. o.) írt: „Számos konferencián, beszélgetésekben, munkahelyeken tapasztalhatjuk, hogy az értelmi akadályozottsággal élő embereknek van véleményük, sok fontosat, hasznosat, jót tudnak mondani életformájukról." Ugyanakkor tapasztalatot jelentet az is, hogy azok, akik nem tudták megfogalmazni, hogy miért akarnak részt venni az önkéntes munkában, a 3 hónapos felkészítő időszak során lemorzsolódtak.

Szülők bevonása. Mindezzel párhuzamosan egy szülői értekezlet keretén belül ismertettük a kávéházi projekt lehetőségét, a szándékunkat, hogy gondozottainkkal részt kívánunk benne vállalni. A szülők többsége „kétkedve” fogadta a lehetőséget, mondván, hogy nem tartják alkalmasnak értelmileg akadályozott felnőtt gyermekeiket arra, hogy ezt a feladatot ellássák. Illetve, többen azt is jelezték, hogy félnek a különböző atrocitásoktól is, amik a felszolgálás során érheti gyermekeiket. Szóbeli megerősítéssel, magyarázattal sikerült rábeszélni a szülőket, hogy támogassák ezt a lehetőséget. „Nem ritkák a téves értelmezések, mint például az, hogy amit kíván, nem kell komolyan venni, olyasmire vágyik, amire úgysem képes, valamint a bizonytalanságok: »és mi lesz, ha nem tud megfelelni, megbízhatok-e benne, a nagyobb önállóság kapcsán vállalhatom-e a kockázatot « erősen ott élnek a szülői, nevelői gondolkodásban.” (Hatos, 2000, 22. o.) Itt, fontos megemlítenem, hogy nem a szülők, hanem az ellátottak lettek megkérdezve, hogy részt kívánnak-e venni az önkéntes felszolgálásban, hiszen mint Hatos, Kisgyörgyné és Stollár (2004, 40. o.) megjegyzik: „Társadalmilag erősíteni kell a fogyatékossággal élő emberek önszerveződését, érdekérvényesítését, be kell vonni őket a róluk szóló intézkedések tervezésébe, megalkotásába, biztosítani kell részvételüket a döntéseknél is." .

Kávéház kiválasztása. Következő lépésként a megvalósítás helyszínéül szolgáló kávéházat kellett felkeresnünk, ahol vállalják, hogy két héten keresztül felnőtt értelmileg akadályozott személyeknek adnak lehetőséget elképzelésünk megvalósításához. Elsőként megkerestünk egy felkapott forgalommal rendelkező orosházi kávéházat, mely pár hét gondolkodási idő után kérésünket elutasította. Ezek után egy kevésbé forgalmas kávéházat látogattunk meg ellátottjainkkal és kérésünkkel. A tulajdonos pár nap gondolkodási idő után igent mondott, lehetőséget teremtve arra, hogy a projektet el tudjuk indítani.

\section{Felkészítés, záróvizsga}

„Az eredményes munkavégzés lehetőség az akadályozottság kompenzálására. Eredményes azonban csak akkor lesz, ha a személyt alkalmassá tesszük rá.” írja Varga (2005, 155. o.). 
Ennek szellemében 2015. április 20-án kezdtünk el - mentortársammal, egyben munkatársammal Muszka Lillával - egy három hónapos felkészítést. A felkészítés során többek között szócsíkok bevonásával (1. ábra), a különbségekre történő figyelem felhívással, halmazok képzésével (például mi a különbség a jó és a rossz megjelenésű személy között?), köszönési formákkal, illemszabályok megismerésével stb. igyekeztünk hatni. Ezt követően szituációs gyakorlatokkal a felszolgálás folyamatát gyakoroltuk először mentoros bemutatással, majd a felszolgáló jelöltek aktív bevonásával a kávézóból elkért itallap felhasználásával. Minden gyakorlat után átbeszéltük a hibákat, erősítettük tapasztalatainkat.

\section{1. ábra: példa a felkészítés során alkalmazott szócsíkokra (forrás: a Szerzö)}

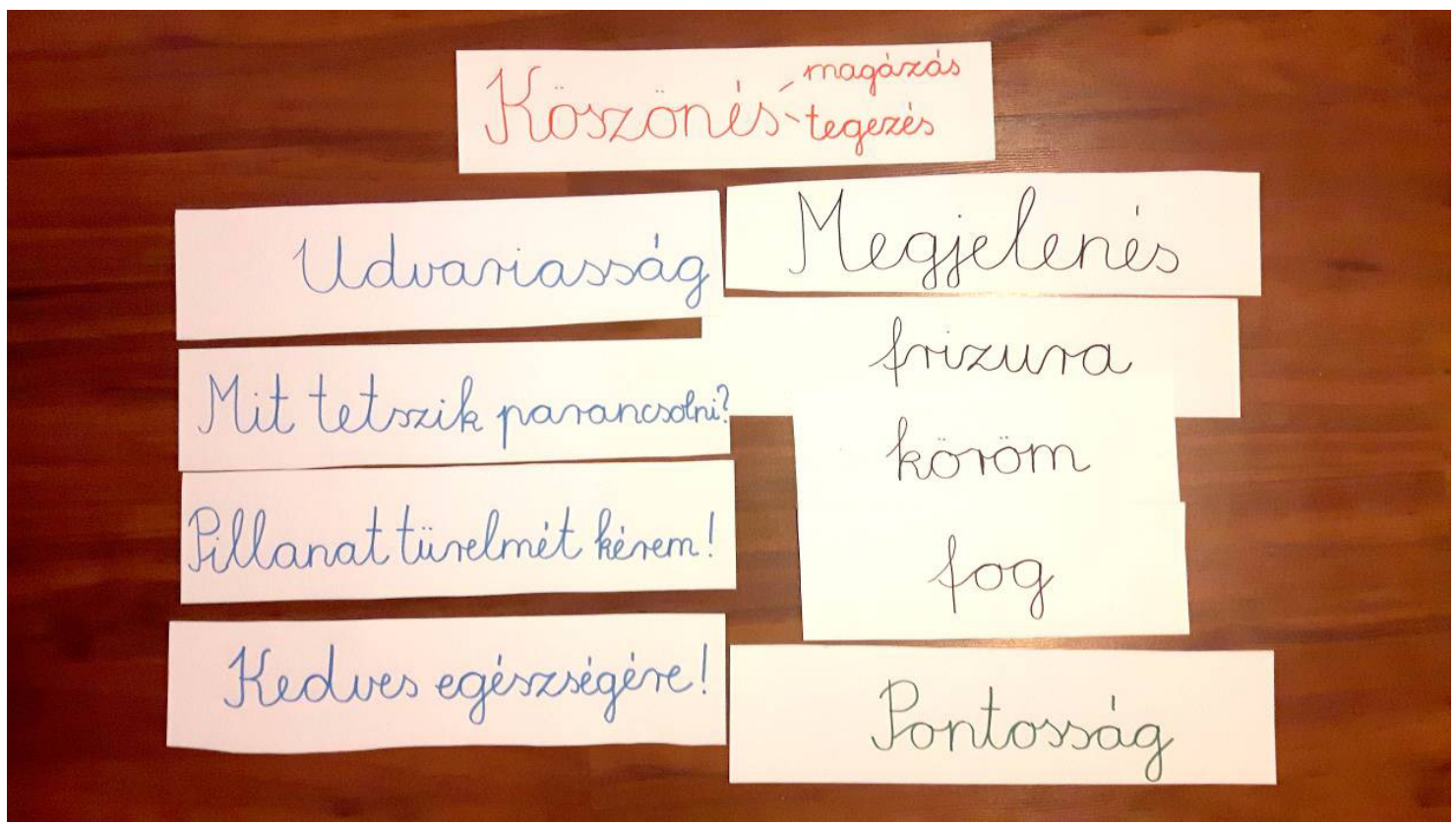

Több alkalommal kimentünk a Caffé Sempre kávéházba, figyelve a felszolgálás folyamatait, ezzel párhuzamosan pedig egy-egy felszolgálást klubtagjainkkal átvállaltunk, erősítve feladathelyzetbe hozásukat, enyhítve szorongásaikat. Hétről hétre érezhetővé vált fejlődésük mellett, munkában való teljesíteni akarásuk.

A három hónapos elméleti, gyakorlati oktatást egy záróvizsgával zártuk, melyre elöre elkészített szituációs felszolgálói feladatokat tartalmazó tételsorokat készítettünk. A vizsgázók egyesével léptek be a terembe, ahol egy rövid bemutatkozást követően ismertetniük kellett a felszolgálás 5 lépését. A szóbeli kérdés megválaszolása után - szituációs feladatokat tartalmazó - tételek közül kellett húzniuk a vizsgázóknak, és az adott feladatot kellett mentori közremüködéssel teljesíteniük. A folyamatot két kívülálló személy, a klubvezető és egy felszolgálói múlttal rendelkező személy előtt kellett teljesíteniük. Összességében elmondható, hogy a vizsgázók összeszedetten, a feladatra koncentrálva, jól teljesítettek. Ünnepélyes keretek között oklevél lett számukra átadva (2. ábra). 
2. ábra: az oklevelek büszke tulajdonosai. Forrás: a Szerzö. (Szerkesztöi megjegyzés: a Szerzö a szerkesztöség számára benyújtotta a képen látható személyek gondviselöitöl származó nyilatkozatot, arról, hogy jelen tanulmányban e képek megjelenhetnek).

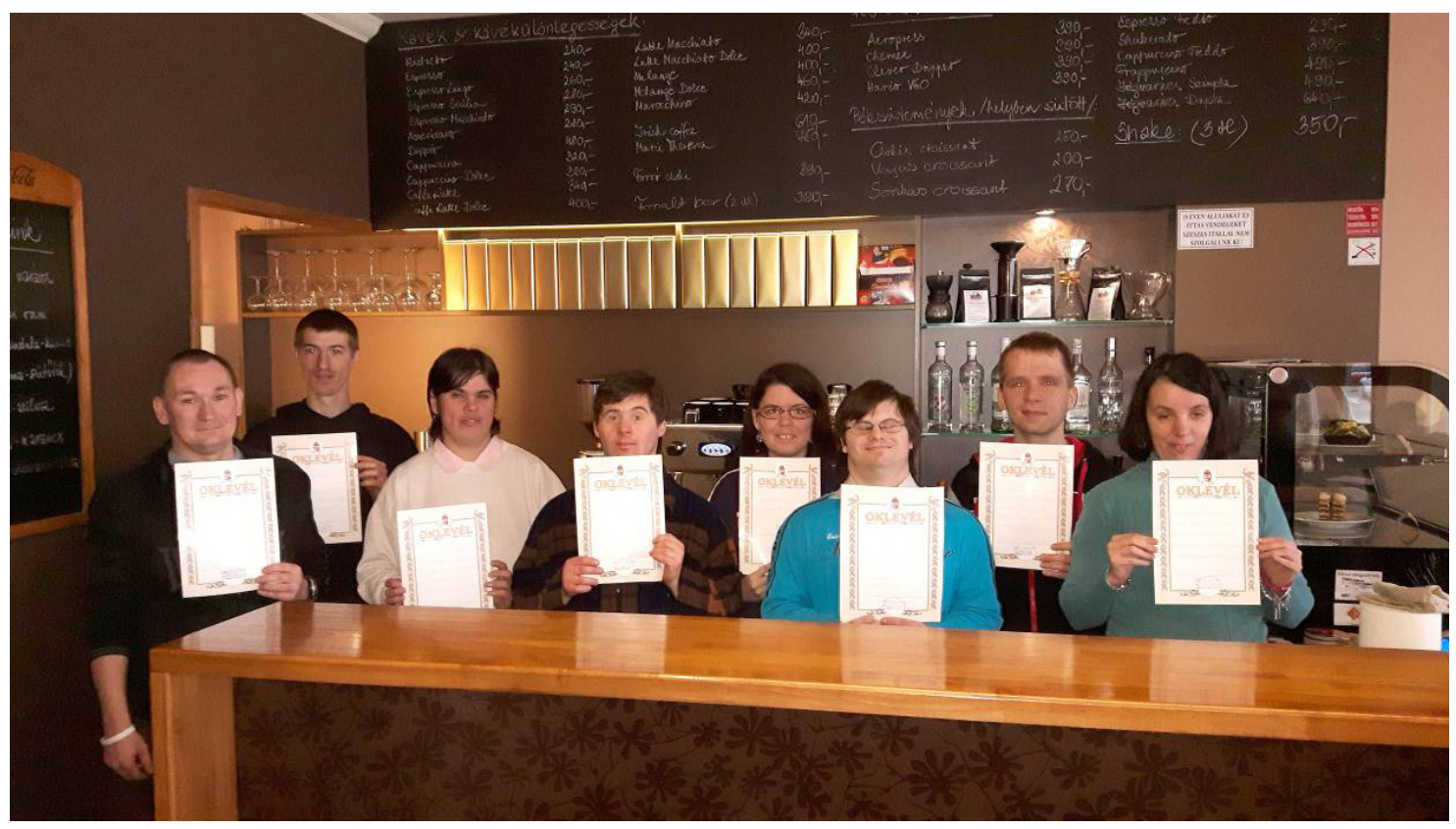

3. ábra: a szórólap. Forrás: a Szerző. (Szerkesztöi megjegyzés: a Szerzö a szerkesztőség számára benyújtotta a képen látható személyek gondviselöitől származó nyilatkozatot, arról, hogy jelen tanulmányban e képek megjelenhetnek)

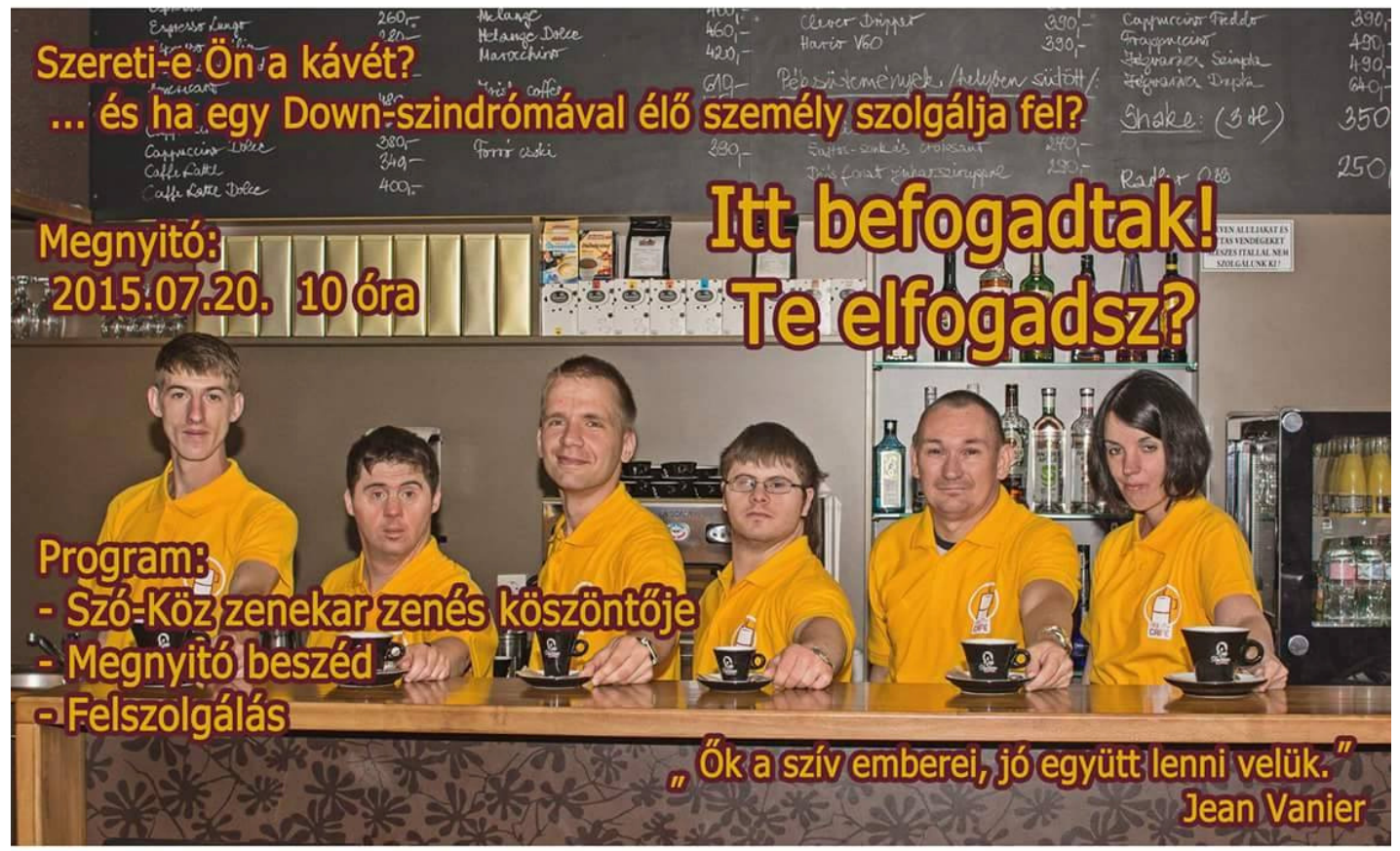




\section{Média}

A kávéházi felszolgálással kapcsolatos eseményeinkről folyamatosan beszámoltunk egy Facebook oldalon, ezzel is tájékoztatva az ismerősöket az éppen aktuális fejleményekről. Fotós kollégát hívtunk, hogy a levizsgázott klubtagjainkat felszolgálós egyenruhában a kávéház helyszínén lefotózza. Az elkészült fotókból mentortársammal kettőt kiválasztottunk, melyekre a szöveget összeállítottuk és továbbvittük szórólapszerkesztésre. Az elkészült szórólapjainkat (3. ábra) a város föbb pontjain és a Facebook oldalon terjesztettem, reklámoztam. Sokan szóban, a szórólapterjesztések közben, illetve írásban, a Facebook oldalon ígéretet tettek arra, hogy el fognak jönni, mivel nagyon jó dolognak tartják ezt a fajta kezdeményezést. Természetesen olyanok is akadtak, akik nem fogadták el szórólapjainkat, a lehetőségtől teljesen elhatárolódtak...

\section{Megnyitó, munkába állás}

2015.07.20.-án ünnepélyes keretek között, a pécsi Fogd a Kezem Alapítvány Ability Cafés felszolgálóival közösen sor került a kéthetes önkéntes munka elindítására. A város lakossága felöl a megnyitóra kevesen jöttek el, az érdeklődők száma minimális volt. A 8 mentoráltból (képességek szerint) 2 fös csoportokat alkottunk. Az így kialakult 4x 2 csoportot egymás között is felosztottuk, melynek fontos szerepe volt abban, hogy mentori figyelmünket minden esetben az általunk felügyelt felszolgálókra összpontosítsuk. Minden kétórás váltás idején, illetve a müszak végén megbeszéltük az aznapi tanulságokat. Felkészített pincéreink izgatottan munkába álltak tehát, mely kezdeti izgalom 1-2 nap elteltével sikeresen átváltott egy magabiztosabb felszolgálói attitüdbe (4. ábra). Az első napokban azonban gondozottaink fokozottan igényelték mentoraik fizikai közelségén túl, a szóbeli megerősítéseket is. Volt olyan mentoráltunk, aki minden egyes vendég kiszolgálása után megkérdezte mentorát, hogy: „Milyen voltam?”. A mentor pedig, minden egyes kérdésre azt válaszolta, hogy: „Nagyon ügyes vagy és mi mindannyian nagyon büszkék vagyunk Rád, Rátok! A feladatot kedves udvariassággal, figyelmesen, teljes koncentrációval végzitek".

4. ábra: felszolgálás közben. Forrás: a Szerzö. (Szerkesztői megjegyzés: a Szerzö a szerkesztöség számára benyújtotta a képeken látható személyek gondviselöitöl származó nyilatkozatot, arról, hogy jelen tanulmányban e képek megjelenhetnek)

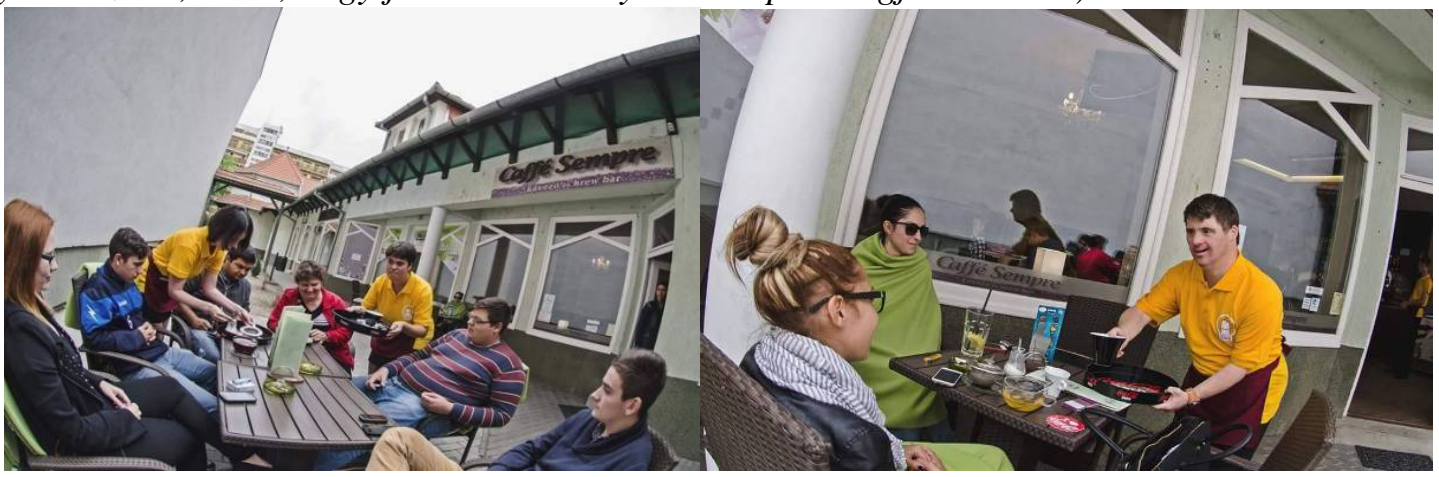

\section{A program lezárása}

A két hét eltelte után a felszolgálás helyszínén, a Caffé Sempre kávéházban - az önkéntes felszolgálók és azok szülei előtt -, mentori feladatom zárásaként összesítő beszédet mondtunk, melyben a két hét tapasztalatait foglaltuk össze. Majd ezek után átadtuk a szót az önkéntes 
felszolgálóknak, akik egymás után, örömmel a hangjukban mesélték el, hogy mit kaptak ebben a két hétben és, hogy nagyon sajnálják, hogy nem dolgozhatnak tovább. Megszerették a felszolgálói munkakört. Nemcsak szüleiknek, mentoraiknak, de önmaguknak is bizonyítottak. Bebizonyosodott, hogy sikeresen véghez tudták vinni a feladatot, mely által fontosnak érezhették magukat. A szülök közül többen szót kértek, hogy megköszönhessék azt a felkészítést, amit mentortársammal véghezvittünk, illetve azt a két hetet, melyben látták gyermekeiket a felszolgálói munkakörben kiteljesedni. A kezdeti bizonytalanságot, melyet a projekt elején éreztek, akkora egy olyanfajta megtapasztalás követett, melynek hozadékát otthoni környezetükben is többen észrevették, többen jelezték. Gyermekeik az otthoni családi környezetben is udvariasabban viselkedtek, illetve szívesen felszolgálták szüleiknek a kávét. Végezetül pedig, a Caffé Sempre Kávéház tulajdonosa, Csiszár Béla mondta el pár mondatban, hogy nagyon örült annak, hogy testközelben is megtapasztalhatta, hogy milyen sokra képesek azok, akik az élet több területén is akadályozottak. Illetve kiemelte, hogy várja a folytatást...

\section{Konklúzió}

Vannak még feladataink a társadalmi érzékenyítés területén (v.ö.: Mező és Mező, 2015). A két hét alatt a felszolgálást ismerőseink, barátaink vették igénybe, illetve olyan vendégek, akik véletlenül tévedtek oda, ugyanis, egy kevésbé forgalmas kávéházról volt szó. Bár, a megnyitó elött sokan gratuláltak és nagyszerü dolognak tartották, hogy akadályozottsággal élő személyek fognak felszolgálni, a velük való találkozást már sokan nem merték vállalni. Többen mondták, hogy a fogyatékkal élő személlyel való találkozás során félnek attól, hogy esetleg olyan helyzet adódik, amit nem tudnak kezelni. Erre azt válaszoltuk, hogy amit kaphatnak egy udvarias és figyelmes felszolgálás mellé az egy kedves mosoly, esetleg egy simogatás lehet, ami, egy „,normál” felszolgálás esetében nem biztos, hogy elöfordul. Mindebből jól látható, hogy a felszínen elfogadott akadályozottsággal élő ember az emberi kapcsolatok valós, konkrét helyzeteiben elutasított. Két fö célkitüzés fogalmazódott meg bennünk arra a majd egy éves időszakra, amíg a következő - előreláthatólag 2016. május végére újra megrendezésre kerülő - önkéntes kávéházi felszolgálás elkezdődik. A célok meghatározásakor egy célcsoportra, a felnövekvő nemzedékre és pedagógusaikra összpontosítottunk. Az egyik célkitüzésünk, hogy ki kell menni az iskolákba, elméleti érzékenyítö órákat kell adni a fogyatékos képröl. Interaktív módon meg kell ismertetni a diákokkal az elöítélet, a sztereotípia, a másság fogalomkörét. Azért van erre szükség, hogy a konkrét találkozási helyzetekben - mely ép és akadályozott személyek között jön majd létre -, a szociális távolságtartás az épek felől a lehető legkisebb legyen. Másik fontos cél, hogy olyan időpontot keressünk az ismétlésre (az elöbbiekben megemlített 2016. május vége), mely oktatási időszakra esik, lehetőséget teremtve arra, hogy az iskolákban, ahol megtörténtek az elméleti érzékenyítő órák, a pedagógusok kihozzák osztályaikból azon diákokat, akik figyelme ráirányítódott a fogyatékosokra, igényt éreznek a velük való találkozásokra, a személyes kontaktusokra.

\section{Zárógondolatok}

Szerencsésnek érzem magam, hogy, mint mentor azt a folyamatot végigvezethettem, melyben a kezdeti kiválogatástól, egészen a „felszolgálói színpadra” történő felemelésig gondozottaimat mentortársammal felkészíthettem, felemelhettem. Mert ez egyfajta felemelés részemről. Képessé tenni a gyengébbet arra, hogy gyakorlással, irányított segítséggel, ott állva a háttérben (vele együtt, de mégis a színfalak mögött) segítve öt, hogy azt a feladatot, amire 
képesnek érzem őt, ellássa. Mindezzel együtt, sikerélményhez juttatom, segítem, hogy boldog legyen, hogy beteljesedjen... Vele együtt örülni a sikernek az egyik legcsodálatosabb érzés annak, aki a gyógypedagógián belül a pedagógiai kísérést választotta hivatásának.

\section{Irodalom}

Hatos Gy. (2000). Értelmileg akadályozott felnöttek pedagógiai kísérése. ELTE BGGYFK, Budapest. 22.

Hatos Gy. (2008). Az értelmi akadályozottsággal élő emberek: Nevelésük, életük. APCStúdió, Gyula. 300.

Hatos Gy., Kisgyörgyné Cziráki Andrea és Stollár János (2004). Fogyatékosok szociális ellátása, rehabilitációja. Nemzeti Család és Szociálpolitikai Intézet, Budapest. 40.

Mezö F. és Mező K. (2015): Gyógypedagógiai problémákra érzékenyítő játékok (nemcsak óvodapedagógusoknak) In Mező K. (szerk.). Játékkal a különleges bánásmódot igénylö gyermekekért. Bíbor Kiadó, Miskolc. 2015. pp. 55- 74.

Vanier, J. (1982). A részvét forrásvidékén. In Sántha M. (szerk.). Szegénységünk kincse. Eisenstadt: Prugg Verlag. 88.

Vanier, J. (2008). Férfinak és nönek teremtette. Letöltés: 2008.06.06. Web: http://www. ppek.hu/text/vanier01.txt

Varga I. (2005): Az értelmileg akadályozott fiatalok munkára felkészítése. In Varga I. (szerk.). Speciális didaktika. APC Stúdió, Gyula, 2005. 154-178.

Vasek, S. (2006). Speciális diagnosztika. APC-Stúdió, Gyula. 